\title{
Analisis Kesiapsiagaan Bencana Pada Guru Sekolah Dasar
}

\author{
Syahrial Ayub' ${ }^{*}$, Muh.Makhrus¹, I Wayan Gunada1, Muhammad Taufik1 \\ ${ }^{1}$ Program Studi Pendidikan Fisika, Fakultas Keguruan dan Ilmu Pendidikan Universitas Mataram, Mataram, Indonesia
}

DOI: $10.29303 /$ jppipa.v6i1.281

Citation: Ayub, S., Makhrus, M., Gunada, I. W., Taufik, M. 2020. Analisis Kesiapan Bencana pada Guru Sekolah Dasar. Jurnal Penelitian Pendidikan IPA (JPPIPA). 6(1). pp. 52-56.

Article history

Received: May $31^{\text {th }} 2019$

Revised: November $27^{\text {th }} 2019$

Accepted: December $22^{\text {th }} 2019$

*Syahrial Ayub: Program Studi Pendidikan Fisika, Fakultas

Keguruan dan Ilmu Pendidikan Universitas Mataram, Mataram, Indonesia.

Email: syahrial.ayub@gmail.com

\begin{abstract}
The purpose of this study was to determine the level of teacher preparedness in primary schools against natural disasters. The research sample was 15 teachers from SD N 6 Mataram. Data collection is done through questionnaires consisting of 5 aspects of disaster, knowledge and signs, impacts, risks and efforts to reduce, preparedness and procedures and first aid tools for victims. We results obtained are (1) knowledge and signs of the occurrence of disasters are in the less category $(56.11 \%)$. (2) the impact caused if a disaster occurs is in the less category (49.33\%). (3) Risk and efforts to reduce disaster risk in the good category $(73.33 \%)$. (4) Disaster preparedness in the good category (79.05\%), and (5) victim first aid procedures and tools in the less category (53.33\%). Based on the results, it can be concluded that the level of preparedness of teachers in facing disasters in SD Negeri 6 Mataram is in the sufficient category of $61.71 \%$. Therefore, socialization and knowledge related to disaster preparedness for teachers in primary schools need to be improved.
\end{abstract}

Keywords: Analysis; preparedness; disaster; teacher; elementary school

Abstrak: Tujuan penelitian ini adalah mengetahui tingkat kesiapsiagaan guru di sekolah dasar terhadap bencana alam. Sampel penelitiannya adalah 15 orang guru SD Negeri 6 Mataram. Pengumpulan data dilakukan melalui penyebaran angket yang terdiri dari 5 aspek kebencanaan, yaitu pengetahuan dan tanda-tanda, dampak, resiko dan upaya mengurangi, kesiapsiagaan serta prosedur dan alat pertolongan pertama pada korban. Hasil yang didapat adalah (1) pengetahuan dan tanda-tanda akan terjadinya bencana berada pada kategori kurang $(56,11 \%)$. (2) dampak yang ditimbulkan bila terjadi bencana berada pada kategori kurang (49,33\%). (3) Resiko dan upaya mengurangi resiko bencana pada kategori baik $(73,33 \%)$. (4) Kesiapsiagaan menghadapi bencana pada kategori baik $(79,05 \%)$, dan (5) prosedur dan alat pertolongan pertama korban pada kategori kurang $(53,33 \%)$. Berdasarkan hasil keseluruhan, dapat disimpulkan tingkat kesiapsiagaan guru menghadapi bencana di SD Negeri 6 Mataram berada pada kategori cukup sebesar 61,71\%. Olehkarena itu, sosialisasi dan pengetahuan berkaitan dengan kesiapsiagaan dalam menghadapi bencana pada guru di sekolah dasar perlu ditingkatkan.

Kata kunci: Analisis; kesiapsiagaan; bencana; guru; sekolah dasar

\section{Pendahuluan}

Bencana gempa bumi dan tsunami di Aceh dan Sumatera Utara yang terjadi pada tahun 2004 tergolong bencana dahsyat bahkan membawa dampak ke wilayah yang lebih luas seperti Sri Lanka. Beberapa penelitian yang dilakukan setelah bencana, menyebutkan bahwa banyaknya jumlah korban disebabkan para korban tidak mempunyai pengetahuan tentang ancaman gempa dan tsunami. Gempa bumi 
yang disebabkan oleh pelepasan tekanan dari lempengan yang bergerak, semakin lama semakin membesar dan akhirnya mencapai pada keadaan dimana tekanan tersebut tidak dapat ditahan oleh pinggiran lempengan (Ella, 2008)

Gempa bumi yang terjadi di bawah laut mengakibatkan terjadinya gerakan kerak bumi ke atas dan ke bawah yang kemudian menyebabkan dasar laut naik dan turun secara tiba-tiba. Pergerakan naik dan turun dasar laut ini seterusnya menggerak-kan air laut, menciptakan pergerakan gelombang yang kuat dan ketika gelombang ini sampai di pantai atau daratan, kecepatannya melambat dan tumbuh menjadi tembok air yang tinggi (Ella, 2008).

Dampak primer yang ditimbulkan dari bencana gempa bumi terdiri dari gonjangan tanah dan getaran tanah. Guncangan tanah dapat menyebabkan kerusakan dan kehancuran bangunan serta kemungkinan timbulnya tsunami yang merupakan bencana sekunder akibat gempa bumi yang berpusat di dasar laut (PSBUGM, 2009).

Lombok sebagai salah satu pulau di wilayah Indonesia yang sangat rentan terjadinya gempabumi. Baru baru ini di tahun 2018 antara bulan Juli sampai Agustus pulau Lombok diguncang 4 kali gempa bumi berkekuatan besar, yaitu 29 Juli 2018 kekuatan 6,4 SR, 5 Agustus 2018 kekuatan 7 SR, 9 Agustus 2018 kekuatan 6,2 SR dan 19 Agustus 2018 berkekuatan 7 SR ditambah dengan rentetan gempa susulan yang mencapai 2500 kali. Hal ini terdampak luar biasa pada masyarakat di pulau Lombok terutama di daerah pantai, pegunungan dan perkotaan. Ditandai dengan hancurnya bangunan dan infrastruktur di daerah yang terdampak dan yang sangat memilukan adalah terdapatnya korban ratusan korban jiwa pada rentetan gempa Lombok ini. Hasil observasi dan studi pendahuluan menunjukkan bahwa kesadaran masyarakat terhadap gempa bumi sangat kurang dan mitigasi gempa bumi juga sangat kurang. Gempa bumi merupakan bencana alam yang tidak dapat diprediksi kapan terjadinya sehingga bisa terjadi tiba-tiba seperti saat bekerja, tidur, bermain, dan bahkan juga saat belajar di sekolah. Anak-anak adalah kelompok yang paling rentan menjadi korban gempa bumi demikian juga guru dan perangkat sekolah lainnya. Maka dari itu mereka sangat perlu dibekali konsep gempa bumi secara umum konsep bencana. Ada beberapa jenis bencana lain yaitu: tsunami, tanah longsor, banjir, kekeringan, badai dan bencana gunung api. Guru sebagai ujung tombak di sekolah merupakan orang yang sangat menentukan bagi peserta didik untuk dapat memahami berbagai aspek yang dibutuhkan tentang kesiapsiagaan bencana. Kesiapsiagaan merupakan salah satu upaya yang dilakukan untuk mengantisipasi kemungkinan terjadi bencana untuk meng-hindari adanya korban jiwa, kerugian harta benda dan perubahan tata kehidupan masyarakat di kemudian hari (Sutton, 2006). Menurut BNPB, (2012) kesiapsiagaan adalah serangkaian kegiatan yang dilakukan untuk mengantisipasi bencana melalui pengorganisasian serta melalui langkah yang tepat guna dan berdaya guna. Sedangkan (Nurmayani, 2018) mendefinisikan kesiapsiagaan mejadi lebih luas yaitu "meminimalisir akibat-akibat yang merugikan dari suatu bahaya lewat tindakan-tindakan pencegahan yang efektif, rehabilitasi dan pemulihan untuk memasti-kan pengaturan serta pengiriman bantuan dan pertolongan setelah terjadi bencana secara tepat waktu dan efektif'.

Upaya kesiapsiagaan yang dilakukan pada saat bencana mulai teridentifikasikan, antara lain; (a) pengaktifan pos-pos siaga bencana dengan segenap unsur pendukung, (b) pelatihan siaga/simulasi/gladi/ teknis bagi setiap sektor penanggulangan bencana (SAR, sosial, kesehatan, prasarana dan pekerjaan umum), (c) inventarisasi sumber daya pendukung kedaruratan, (d) penyiapan dukungan dan mobilisasi sumber daya/ logistik, (e) penyiapan sistem informasi dan komunikasi yang cepat dan terpadu untuk mendukung tugas kebencanaan, (f) penyiapan dan pemasangan instrumen sistem early warning, (g) penyusunan contingency plan.

Pada penelitian ini digambarkan kesiapsiagaan guru dalam menghadapi bencana terutama di SD Negeri 6 Mataram. Ada 5 aspek besar yang digambarkan pada penelitian ini, yaitu: (1) pengetahuan dan tanda tanda akan terjadinya bencana, (2) dampak yang ditimbulkan bila terjadi bencana, (3) resiko dan mengurangi resiko bencana, kesiapsiagaan menghadapi bencana, dan (5) prosedur dan alat pertolongan pertama pada korban. Tergambarnya kesiapsiagaan guru dalam menghadapi bencana akan menjadi dasar utama untuk menanamkan kesadaran bencana pada peserta didik. Kesiapsiagaan guru dan peserta didik akan mengurangi resiko bencana yang terjadi.

Menurut Badan Nasional Penanggulangan Bencana, (2012) risiko bencana adalah potensi 
kerugian yang ditimbulkan oleh bencana pada suatu wilayah dan kurun waktu tertentu, yang dapat berupa kematian, luka, sakit, jiwa terancam, hilangnya rasa aman, mengungsi, kerusakan atau kehilangan harta, dan gangguan kegiatan masyarakat. Oleh karena itu, pengurangan risiko bencana merupakan rencana terpadu yang bersifat lintas sektor dan lintas wilayah serta meliputi aspek sosial, ekonomi dan lingkungan. Dalam implementasi, kegiatan pengurangan risiko bencana nasional akan disesuaikan dengan rencana pengurangan risiko bencana pada tingkat regional dan internasional. Dalam hal ini masyarakat sebagai subjek dan objek sekaligus sasaran utama upaya pengurangan risiko bencana dengan berupaya mengadopsi serta memperhatikan kearifan lokal dan pengetahuan tradisional yang ada dan berkembang dalam masyarakat.

Simulasi, sosialisasi dan pelatihan tentang penanggulangan bencana yang pernah dilakukan oleh pemerintah NTB maupun dari berbagai organisasi sepertinya tidak mempunyai dampak yang baik. Hal ini dikarenakan masih adanya korban jiwa akibat bencana. Atas dasar hal tersebut di atas, maka tujuan penelitian ini untuk mengkaji pengetahuan dan tanda tanda, dampak, resiko dan upaya mengurangi, kesiapsiagaan, prosedur dan alat pertolongan pertama pada korban bencana.

\section{Metode}

Penelitian ini menggunakan metode kualitatif dan kuantitatif, dengan variabel penelitian yaitu kesiapsiagaan menghadapi bencana yang terdiri dari aspek pengetahuan dan tanda tanda akan terjadinya bencana, dampak yang ditimbulkan bila terjadi bencana, resiko dan mengurangi resiko bencana, kesiapsiagaan menghadapi bencana, dan prosedur dan alat pertolongan pertama pada korban. Data penelitian ini didapat dari hasil pemberian kuesioner. Sampel penelitian yaitu guru SD Negeri 6 Mataram. Selanjutnya, data kuantitatif yang didapat dari perhitungan kuesioner dideskripsikan berdasarkan data tambahan berupa pengamatan selama penelitian dan dikaitkan dengan penelitian terdahulu yang sesuai. Populasi dalam penelitian ini adalah seluruh guru SD Negeri 6 Mataram. Sampel penelitian ini adalah lima belas orang guru SD Negeri 6 Mataram yang diambil secara random (random sampling). Data didapat melalui kuisioner yang terdiri dari lima aspek kesiapsiagaan. dan serta divalidasi oleh ahli untuk bahasa dan penulisannya. Selain itu, data pendukung didapat dari dokumentasi, studi literatur, dan lainnya yang dibutuhkan dengan melibatkan guru dan pegawai di SD Negeri 6 Mataram. Penilaian dilakukan menggunakan skala Likert (Sugiyono, 2013) dengan memberikan nilai tertinggi 1 untuk jawaban setuju, nilai 0 untuk jawaban tidak setuju Untuk mendapatkan prosentase dari setiap aspek digunakan rumus berikut :

$$
\mathrm{Pn}=\frac{\text { skor aspek } \mathrm{N}}{\text { skor maksimum aspek } \mathrm{N}}
$$

dimana, Pn adalah prosentase aspek N. Skor aspek $\mathrm{N}$ adalah jumlah jawaban yang sesuai dengan konsep pada setiap aspek kebencanaan dan skor maksimum aspek $\mathrm{N}$ adalah jumlah skor total pada setiap aspek kebencanaan. Aspek kebencanaannya adalah (1) pengetahuan dan tanda-tanda terjadinya bencana, (2) dampak bencana, (3) resiko dan upaya mengurangi dampak bencana, (4) kesiapsiagaan bencana alam, dan (5) prosedur dan pertolongan pertama pada korban. Instrumen yang digunakan dalam penelitian terlebih dahulu divalidasi dan dilakukan uji coba terbatas, yang bertujuan untuk mengetahui validitas dan reliabilitas dari kuesioner untuk ke 5 aspek kesiapsiagaan. Validitas merupakan suatu ukuran yang menunjukkan tingkat kesahihan suatu tes (Arikunto, 2006). Teknik analisa data untuk data kualitatif yang digunakan dalam penelitian ini sesuai dengan pernyataan Moleong, (2007) bahwa proses analisa data kualitatif dimulai dengan menelaah seluruh data yang tersedia dari berbagai sumber, yaitu dari wawancara, pengamatan yang sudah dituliskan dalam catatan lapangan, dokumen pribadi, dokumen resmi, gambar, video dan sebagainya. Langkah berikutnya adalah mengadakan reduksi data atau memilih hal-hal pokok yang sesuai dengan fokus penelitian. Reduksi data merupakan suatu bentuk analisis yang menggolongkan, mengarahkan, mengorganisasikan dan membuang data yang tidak diperlukan. Oleh karena itu, reduksi dilakukan dengan jalan abstraksi yang merupakan usaha membuat rangkuman serta pernyataan yang tetap. Setelah data direduksi maka dipilih data yang diperlukan dan dikelompokkan berdasarkan informasi yang telah disusun. Apabila didapatkan data yang kurang maka dilakukan penyempurnaan data dengan cara mencari kembali baik melalui wawancara atau dokumen yang ada. Tahap terakhir dari analisa data adalah mengadakan pemeriksaan keabsahan data sebelum pemaparan dan analisa terhadap data untuk menarik kesimpulan dari hasil penelitian. 


\section{Hasil dan Pembahasan}

Berdasarkan kelima aspek kesiapsiagaan bencana pada guru SD Negeri 6 Mataram nilai persentase jawaban untuk semua guru tergambar pada tabel 1:

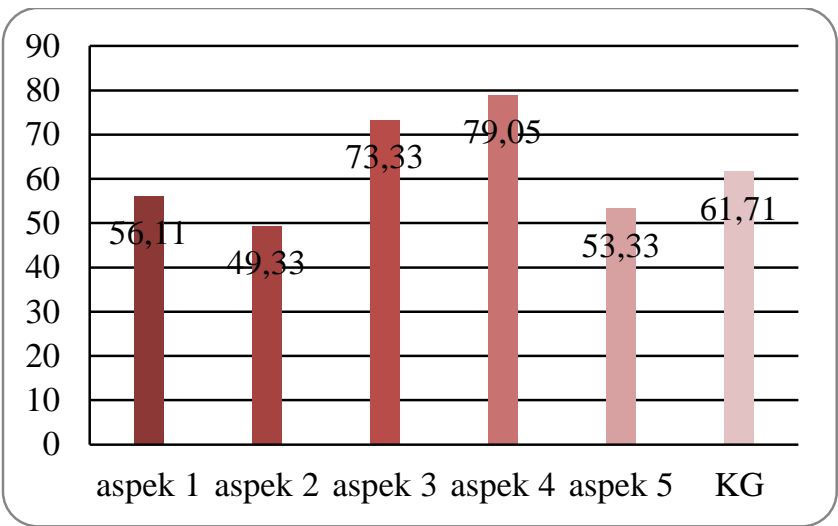

Tabel 1 : Prosentase 5 Aspek Kesiapsiagaan

Secara rinci aspek 1 merupakan pengetahuan dan tanda-tanda akan terjadinya bencana tergambarkan $56,11 \%$, aspek 2 yaitu dampak yang ditimbulkan bila terjadi bencana 49,33\%, aspek 3 yaitu resiko dan upaya mengurangi resiko bencana $73,33 \%$, aspek 4 yaitu kesiapsiagaan guru dalam menghadapi bencana $79,05 \%$, aspek 5 yaitu prosedur dan alat pertolongan pertama pada korban $53,33 \%$ sedangkan secara keseluruhan kesiapsiagaan guru dalam menghadapi bencana adalah $61,71 \%$.

Berdasarkan hasil sebaran kuesioner tersebut, tergambar aspek kebencanaan yang masuk kategori kurang adalah tentang (1) pengetahuan dan tanda tanda akan terjadinya bencana, (2) dampak yang ditimbulkan bila terjadi bencana, dan (3) prosedur dan pertolongan pertama pada korban bencana. Kurikulum kebencanaan belum ada di sekolah, hal inilah yang menyebabkan aspek (1), (2) dan (3) berada pada kategori kurang karena pada aspek ini merupakan pengetahuan, sikap dan keterampilan yang harus dimiliki guru dalam aspek kebencanaan dan ini harus diajarkan, dilatihkan dan di sosialisasikan pada guru. Oleh karena itu, peningkatan aspek pengetahuan sangat diperlukan karena akan berdampak pada aspek yang lain. Hal ini bertujuan untuk dapat menyelamatkan dan mengurangi banyak korban jiwa, dislokasi, dan kerugian ekonomi yang diakibatkan oleh bencana gempa bumi.
Dari aspek kesiapsiagaan dan upaya mengurangi resiko berada pada kategori baik. Hal ini sesuai dengan bidang mereka sebagai guru harus mempunyai kepekaan yang besar terhadap usaha usaha yang harus dilakukan pada peserta didik bila terjadi bencana saat mereka berada di sekolah, di samping itu guru juga harus mempunyai kepekaan dalam upaya mengurangi resiko bencana. Hal ini sudah dibuktikan secara ilmiah oleh guru di SD Negeri 6 Mataram.

Selain itu, pengalaman dan latar belakang pendidikan mereka juga mendukung dalam menguasai pengetahuan tentang bencana. Hal ini didukung oleh pernyataan Gunawan, (2008), bahwa kesiapsiagaan dalam menghadapai bencana alam didapat dari pengalaman. Oleh sebab itu, dengan pengetahuan yang baik dan mempunyai pengalaman, maka terbentuklah sikap yang baik dan tepat dalam menghadapi bencana. Secara keseluruhan, aspek kebencanaan pada guru SD Negeri 6 Mataram berada pada kategori cukup $(61,71 \%)$. Kesiapsiagaan masyarakat yang tepat dan efektif dalam menghadapi bencana dapat dilihat dari sejauh mana mereka dapat tanggap dalam merespon bencana, yang sesuai dengan pernyataan. Hal ini dapat diketahui dari hasil wawancara dan jawaban kuesioner tentang aspek kesiapsiagaan dalam menghadapi bencana. Selain itu, kesiapsiagaan dalam menghadapi bencana juga dapat mengurangi risiko yang ditimbulkan dari bencana tersebut (Anderson, 2005).

Semua guru yang dilibatkan dalam penelitian adalah mereka yang pernah mengalami bencana gempa bumi di Lombok tahun 2018, sehingga dapat diketahui kesiapsiagaan mereka dalam menghadapi bencana gempa bumi. Hal ini sama dengan pernyataan Priyanto, (2006) yang menyatakan bahwa masyarakat yang belum memiliki pengalaman langsung dengan bencana seringkali mengabaikan kesiapan menghadapi bencana. Berdasarkan pengalaman inilah mereka menjadi lebih siap dalam menghadapi bencana gempa bumi. Analisa ini memberikan gambaran dan informasi kepada kita bahwa pembelajaran kebencanaan pada guru, peserta didik, pegawai dan kepala sekolah harus segera diterapkan pada kurikulum pendidikan di sekolah. Aspek kesiapsiagaan guru dalam menghadapi bencana termasuk dalam kategori baik. Hasil ini dikarenakan sebagian besar mereka mengalami bencana gempa bumi yang terjadi pada bulan Juli sampai dengan Desember 2018 sehingga lebih mempunyai kesiapsiagaan yang tepat dalam mengahadapi bencana gempa bumi. Pengalaman mereka ini kemudian diceritakan kembali kepada 
saudara dan keturunannya sehingga mereka juga dapat mengetahui dan ikut merasakan pengalaman menghadapi bencana gempa bumi yang terjadi.

Gunawan, (2008) menyatakan bahwa pengalaman mengalami bencana dapat membentuk kesiapsiagaan yang tepat, dan pernyataan Nasution, (2011) bahwa pendidikan dan pengalaman merupakan faktor yang dapat mempengaruhi pengetahuan. Aspek ini berisi pertanyaan tentang apa yang dilakukan peserta didik sebelum, saat akan ada tanda-tanda akan terjadi bencana, saat menyelamatkan diri menuju daerah yang aman dan saat yang dilakukan sampai pada daerah yang aman. Pengetahuan, sikap dan keterampilan tentang ini harus terbentuk pada diri peserta didik sehingga timbul tingkat kesadaran terhadap bencana. Hal ini sesuai dengan pernyataan Anderson, (2005) bahwa pengetahuan dan kesiapsiagaan dalam menghadapi bencana dibutuhkan dalam mitigasi komunitas terhadap bencana. Hal yang sama juga dinyatakan oleh LIPI, (2006) bahwa pengetahuan dan sikap mengenai kesiapsiagaan menghadapi bencana adalah kemampuan yang harus dimiliki oleh setiap individu sebagai wujud dari kesiapsiagaan dalam menghadapi bencana. Perubahan tingkah laku peserta didik berkat adanya pengalaman yang diberikan melalui latihan untuk dapat menyelesaikan masalah yang dihadapi (Ismayanti, 2016).

\section{Ucapan Terimakasih}

Penelitian ini terselenggara dari bantuan banyak pihak, terutama dari LPPM Universitas Mataram dan Fakultas Keguruan dan Ilmu Pendidikan Universitas Mataram.

\section{References}

Anderson \& King. 2005. Mitigation of the Impact of Tropical Cyclones in Northern Australia through Community Capacity Enhancement. Volume 10, Issue 3, pp 367-392.

Arikunto, S. 2006. Prosedur Penelitian Suatu Pendekatan Praktek. Jakarta: Rineka Cipta.

Badan Nasional Penanggulangan Bencana. 2012. Peraturan Kepala Banda Nasional
Penanggulangan Bencana Nomor 1 Tahun 2012 tentang Pedoman Umum Desa/Kelurahan Tangguh Bencana. BNPB

Ella dan Usman. 2008. Mencerdasi Bencana. Jakarta: Grasindo.

Gunawan. 2008. Kondisi Sosial Masyarakat dalam Manajemen Bencana. Yogyakarta.

Ismayawati, B. 2016. Pengaruh Model Pembelajaran Berbasis Masalah (PBM) dalam Setting Pembelajaran Kooperatif Tipe TGT dan GI terhadap Kemampuan Berpikir Kritis dan Hasil Belajar Kimia Peserta Didik SMA N 1 Aikmel. Jurnal Penelitian Pendidikan IPA, 2(1), 54-65. Retrieved from https://jppipa.unram.ac.id/index.php/jppipa/a rticle/view/33/33

Lembaga Ilmu Pengetahuan Indonesia (LIPI) UNESCO/ISDR. $2006 . \quad$ Kajian Kesiapsiagaan Masyarakat dalam Mengantisipasi Bencana Gempa Bumi dan Tsunami. Deputi Ilmu Pengetahuan Kebumian Lembaga Ilmu Pengetahuan Indonesia. Jakarta.

Moleong, J. 2007. Penelitian Kualitatif. Bandung: PT Rosdakarya

Nurmayani, L., 2018. Pengaruh Model Pembelajaran Inkuiri Terbimbing Terhadap Hasil Belajar Peserta Didik. Jurnal Penelitian Pendidikan IPA, 4(2), 23-28. Retrieved from https://jppipa.unram.ac.id/index.php/jppi $\mathrm{pa} / \mathrm{article} / \mathrm{view} / 113 / \mathrm{pdf}$

Nasution,S. 2011. Metode Research (Penelitian Ilmiah.).Bumi Aksara. Jakarta

PSB-UGM.2009. Reorientasi Pendidikan Kebencanaan dalam Rangka Pengurangan Risiko Bencana. Seminar Nasional. Reorientasi Pendidikan Kebencanaan Yogyakarta

Priyanto, A. 2006. Promosi Kesehatan Pada Situasi Emergensi Edisi 2. Jakarta.

Sutton, J.,and Tierney,K. $2006 . \quad$ Disaster Preparedness: Concepts, Guidance and Research. University of Colorado. Colorado

Sugiyono. 2013. Metode Penelitian Pendidikan Pendekatan Kuantitatif, Kualitatif, dan $R \& D$. Bandung: ALFABETA. 